Marzena CICHOSZ

DOI : $10.14746 / \mathrm{pp} .2018 .23 .4 .2$

University of Wroclaw

ORCID https://orcid.org/0000-0003-0853-742X

Łukasz TOMCZAK

University of Szczecin

ORCID https://orcid.org/0000-0002-6808-0364

\title{
Implementation of the Quota System \\ in the Regional Assembly Elections: the Analysis of Electoral Results in the Context of Women's Epresentation on Electoral Lists
}

\begin{abstract}
The following article concerns selected aspects of the implementation of the quota system in elections to the regional assemblies (Sejmik wojewódzki) in Poland. This comparative analysis concerns two elections: in 2010 (before the quota system was introduced) and in 2014 (after its introduction). The key questions the authors would like to address involve the number of women represented on the electoral lists in 2010 and 2014 respectively, and the number of mandates in regional assemblies awarded to women before and after the quota system was introduced, as well as the relationship between the position on the electoral list and mandates awarded to female candidates. The authors also focus on the personnel policies of political parties. Out of all regional elections, the regional assembly elections were characterized by the highest level of party dependency.

Introducing the quota system resulted in an increase in the number of women represented on electoral lists, yet it did not help increase the number of mandates awarded to female candidates. One of the reasons for this situation was the strategy adopted when the positions on the electoral lists were awarded by the parties with the largest political support. The representation of women on the upper positions of the electoral lists is smaller than the quota of female representatives imposed by the electoral law, and the larger number of women on the positions further below on the electoral lists translates into smaller chances of these candidates gaining a mandate. The source data for this research analysis comes from the National Electoral Commission.
\end{abstract}

Key words: women, quota system, elections, regional assemblies, political parties

$E^{2}$ mploying institutionalized methods to support women's participation in politics depends on the type of electoral system. In proportional representation, such a method is constituted by establishing a particular quota or parity to represent both genders when placing candidates on electoral lists. The quota mechanism consists of indicating the minimum percentage of male and female candidates represented on the lists. Parity is a specific type of quota, where half the available slots on a list are allocated to each gender (Musiał-Karg, 2014, p. 68). An additional mechanism conducive to equal opportunities is the zipper system, which entails alternate placing of men and women on electoral lists. To guarantee a quota or parity on electoral lists is one of the postulates proposed by organizations working for women's equality, as well as some political parties. Not only are guarantees of places on electoral lists suggested, but also that political parties should introduce certain rules concerning occupying positions in party structures, assuring a quota or gender parity for women in their midst. These might constitute an 
obligatory statutory requirement which all political entities must obey; they might also be voluntary, internal regulations used by political parties when choosing their candidates. Quotas might be used in relation to candidates, as well as elected party members (Wawrowski, 2007, pp. 592-593).

In Western European parties, introducing parities and specific policies linked to equal opportunities for women has correlated with a growing presence of women in political parties and their representation in parliaments, evident since the 1970s. An exceptionally high increase in female parliamentary representatives has been observed in left-wing parties (Caul, 1999, p. 85), which were among the first to introduce quota systems. The first political party to do so was the Socialist People's Party in Denmark, which in 1977 established a quota of $40 \%$ (Wawrowski, 2007, p. 609). Similarly, left-wing parties were the first political organizations in Poland to introduce minimum quotas for the participation of candidates of a particular gender on electoral lists, as an internal regulation embraced by the parties themselves (Sznajder, 2009, pp. 62-63). This decision resulted from the pressure of the organizations working for women's equality. In the Democratic Left Alliance (Sojusz Lewicy Demokratycznej, SLD), according to a 2001 resolution, the representation of a particular gender could not be smaller than 30\%. A similar approach was adopted by other left-wing parties. However, introducing internal regulations did not necessarily mean that the political parties would abide by them in practice.

Already in the early 1990s, ideas and initiatives concerning legal solutions which would support equal opportunities for men and women in elections appeared in Poland. There were two means by which launching a universally applicable mechanism for gender equality in elections was attempted. One approach posited introducing a quota mechanism as part of the legal act on the equality of men and women, the other - as part of the electoral system. In 1996, a bill on the equality of men and women was drafted by the Women's Parliamentary Group, which, once amended, was again motioned in 1997, yet was not considered by the parliament due to the fact that the Sejm's term had ended. Subsequent bills voted on in 1998 and 2002 were rejected. With regards to the possibility of changing the electoral system, a bill was proposed in 2001 by the MP and Deputy Marshal of the Sejm, Olga Krzyżanowska, on behalf of the Freedom Union (Unia Wolności) (Urbaniak, 2011, p. 70). The motion postulated a minimum quota of $30 \%$ for each gender on the candidate electoral list. However, this bill was also rejected (Fuszara, 2011, pp. 121-122). In 2009, the Women's Congress (Kongres Kobiet) put forward a citizens' initiative bill aimed at increasing the number of women on electoral lists, so that their number would be equal to that of male candidates. This bill was put before parliament in 2010, and subsequent drafts resulted in the proposed parity being reduced to $35 \%$. The legislative act amending the electoral system was adopted in January 2011, and the law concerning quotas was maintained in the Election Law of August 2011, which regulates all types of elections, including those for the decision-making bodies of regions, counties and towns.

Introducing quotas in regional elections necessarily led to an increased percentage of women appearing on electoral lists across the country, but in most constituencies, as in previous elections, it was still less than what the introduced law detailed. The size of constituencies suggested that the percentage of female candidates on electoral lists would be higher than the quota demanded by the legislation. 
Nevertheless, this did not mean that the number of mandates awarded to women would increase. Research shows that, in the situation of ranked voting where the elector may indicate one candidate on a chosen list, an increase in the percentage of representation of a particular group in an electoral list does not have to translate into an increased number of mandates awarded to this group (Norris, 2004, pp. 187-198; Flis, 2012, pp. 80-101). A discussion on equal opportunities for women and men in elections does not only concern the issue of quotas, but also of the placement of candidates on electoral lists. As Małgorzata Fuszara has noted, to provide an elector with the appropriate conditions for making a choice between a man and a woman, "both male and female candidates should be placed proportionally on the electoral lists, and both these groups should be given access to at least similar placing" (Fuszara, 2007, p. 682). The analysis of the results of past elections in Poland, both parliamentary and regional, shows that candidates placed in the initial positions on electoral lists are privileged when it comes to the chances of winning a mandate (Siemieńska, 2005, p. 61; Flis, Gendźwiłł, pp. 7-8, 17-18). For instance, in regional assembly elections, the leaders of the lists are awarded circa $50 \%$ of mandates (Cichosz, Starzyk, 2017, p. 317). On the other hand, Niżyńska's conclusions are more cautious, as, in her analysis of the electoral results of women in regional assembly elections in 2010, she linked electoral chances to the ideological profile of the political parties on whose lists these candidates were placed, thus suggesting that female candidates' results were more correlated to the political preferences of their electors and their open-mindedness towards female candidates than to their placing on the list (Niżyńska, 2011, pp. 8-9).

The purpose of this research was to establish the consequences of introducing quotas in the electoral law in Polish regional elections. Our attention was focused on several selected issues: the number of women on electoral lists, the number of council mandates won by women, as well as the position of women on electoral lists and the connection between their electoral chances and their electoral list placing. The analysis encompassed two regional assembly elections: 2010 and 2014. The former took place before the amendments to the electoral law were made, while the latter was conducted in accordance with the regulations concerning quotas launched in 2011. This choice of data allowed us to observe changes in personnel policies introduced in political parties when recruiting candidates for electoral lists, as well as fluctuations in the number of women represented in regional assemblies before and after the quota system was implemented.

We would like to posit a hypothesis that the introduction of the quota system into, for instance, the regional assembly (Sejmik wojewódzki) elections in Poland resulted in a larger number and percentage of women on electoral lists in 2014 in comparison to elections in 2010, yet it did not translate into greater involvement of women in regional assemblies, which retained their shape after both elections. The reasons behind this preservation of the status quo is the practice of placing female candidates in lower positions on electoral lists, especially by the political entities which are the key ones in regional assembly elections, i.e. the largest political parties, Civic Platform (Platforma Obywatelska RP, PO), Law and Justice (Prawo i Sprawiedliwość, PiS), the Polish People's Party (Polskie Stronnictwo Ludowe, PSL) and the Democratic Left Alliance (Sojusz Lewicy Demokratycznej, SLD). ${ }^{1}$ Among other things, this means that,

${ }^{1}$ In the analyzed elections, SLD registered lists in 2010 as the electoral committee of the political party, and as a coalition with smaller social entities in 2014, named SLD-Lewica Razem (SLD-LR). 
of all candidates placed on first positions on electoral lists, women are represented to a smaller extent than their percentage of all candidates on the list would entail. At the same time, the over-representation of women among the candidates located in the lowest positions on the lists (from $6^{\text {th }}$ position to the last one) can be observed (H1). Some regional differences concerning the representation of women in electoral lists and in the regional assemblies may be also noted. Particular electoral committees have different personnel policies when creating their electoral lists, which means that we can identify regions which are more or less open to women's electoral participation (H2). The scope of this research is as follows:

- the change in the number of women participating in both elections examined here, and their percentage among all candidates, allowing for varieties in particular regions - in this part of the analysis, all electoral committees participating in both elections (48 in 2010 and 53 in 2014) were included in this research;

- the placement of women on electoral lists of the electoral committees participating in the allocation of mandates divided into regions - this analysis concerned, above all, the four largest parties in the country (PO, PiS, PSL, SLD - in 2014 as SLD-Lewica Razem [SLD-Left Together] committee), as well as entities of a regional character, which achieved the election threshold: in four regions in 2010 (Dolnośląskie, Opolskie, Śląskie and Świętokrzyskie) and in 2014 in six regions (Dolnośląskie, Lubuskie, Opolskie, Śląskie, Wielkopolskie and Zachodniopomorskie ${ }^{2}$ ); in total, the research entailed 381 regional lists in 2010 and 373 regional lists in 2014;

- the change in representation of women in regional assemblies in 2010 and in 2014, and their positions on the lists in which they won their mandates. When it comes to the analysis of their placing on electoral lists, the list placements were divided into three groups:

I - first positions, the most important ones, leaders of the list;

II - positions 2 to 5 , within the limits of the minimum number of mandates awarded to a given constituency;

III - the rest of the positions, from position 6 to the end, where most often a very small number of candidates have a chance to win a mandate.

The analysis was performed on the basis of data made available on the websites of the National Electoral Commission.

\section{The number of female candidates and their placement on electoral lists}

A smaller number of candidates participated in the regional assembly elections in 2014 in comparison to the elections of 2010 (see Table 1). Although in 2014 the number

\footnotetext{
Yet, due to the fact that in both cases SLD was the dominant entity, it is justified to compare the results of both committees in these elections.

${ }^{2}$ In 2014, these included the following electoral committees: Non-Party Regional Councillors (KWW Bezpartyjni Samorzadowcy) (Dolnośląskie), Better Lubuskie (KWW Lepsze Lubuskie) (Lubuskie), German Minority (KW Mniejszość Niemiecka) (Opolskie), Autonomous Silesia Movement ( $K W$ Ruch Autonomii Ślaska) (Śląskie), Wielkopolska Now (KWW Teraz Wielkopolska) (Wielkopolskie), Non-Party Zachodniopomorskie (Bezpartyjni KWW Pomorze Zachodnie) (Zachodniopomorskie).
} 
of mandates in regional assemblies decreased (555) in contrast to the 2010 elections (561 mandates), the number of electoral committees participating in the elections increased: from 48 in 2010 to 53 in 2014. Therefore, the smaller number of candidates in 2014 should be linked to the inability of small political entities to put forward electoral lists in all constituencies and to incomplete lists being put forward.

Despite the fact that the number of candidates decreased, the number of women exercising their right to run for office increased by over a thousand (from 2,650 female candidates in 2010 to 3,961 in 2014; see Table 1), and their percentage among all candidates was almost $45 \%$ (44.51\%, to be exact). A list with over $40 \%$ of women was put forward in each of the regions, including those where in 2010 there were fewer than $20 \%$ female candidates in regional assembly elections (Podlaskie).

Table 1

Women on electoral lists in regional assembly elections, 2010-2014

\begin{tabular}{|c|c|c|c|c|c|c|c|}
\hline \multirow{3}{*}{ Region } & \multicolumn{4}{|c|}{ Number of candidates } & \multirow{2}{*}{\multicolumn{3}{|c|}{$\begin{array}{l}\text { \% of women on the electoral } \\
\text { lists }\end{array}$}} \\
\hline & \multicolumn{2}{|c|}{ total } & \multicolumn{2}{|c|}{ women } & & & \\
\hline & 2010 & 2014 & 2010 & 2014 & 2010 & 2014 & difference \\
\hline Wielkopolskie & 540 & 700 & 162 & 316 & 30.00 & 45.14 & +15.14 \\
\hline Kujawsko-Pomorskie & 616 & 541 & 188 & 247 & 30.52 & 45.66 & +15.14 \\
\hline Małopolskie & 669 & 611 & 184 & 263 & 27.50 & 43.04 & +15.54 \\
\hline Dolnośląskie & 549 & 500 & 156 & 217 & 28.42 & 43.40 & +14.98 \\
\hline Lubelskie & 634 & 510 & 179 & 225 & 28.23 & 44.12 & +15.89 \\
\hline Lubuskie & 401 & 498 & 115 & 223 & 28.68 & 44.78 & +16.10 \\
\hline Łódzkie & 585 & 490 & 186 & 220 & 31.79 & 44.90 & +13.11 \\
\hline Mazowieckie & 975 & 997 & 334 & 446 & 34.26 & 44.73 & +10.47 \\
\hline Opolskie & 337 & 459 & 95 & 203 & 28.19 & 44.23 & +16.04 \\
\hline Podlaskie & 359 & 444 & 68 & 201 & 18.94 & 45.27 & +26.33 \\
\hline Pomorskie & 526 & 431 & 174 & 180 & 33.08 & 41.76 & +8.68 \\
\hline Śląskie & 1,047 & 1,077 & 311 & 482 & 29.70 & 44.75 & +15.05 \\
\hline Podkarpackie & 459 & 475 & 124 & 210 & 27.02 & 44.21 & 17.19 \\
\hline Świętokrzyskie & 473 & 377 & 145 & 170 & 30.66 & 45.09 & +14.43 \\
\hline Warmińsko-Mazurskie & 357 & 376 & 108 & 177 & 30.25 & 47.07 & +16.82 \\
\hline Zachodniopomorskie & 377 & 412 & 121 & 181 & 32.10 & 43.93 & +11.83 \\
\hline Poland & 8,904 & 8,898 & 2,650 & 3,961 & 29.76 & 44.51 & +14.75 \\
\hline
\end{tabular}

Source: Own work based on National Electoral Commission data.

The most significant increase in the percentage of women on electoral lists was noted in the following regions: Lubuskie, Opolskie, Podkarpackie, Podlaskie (record-breaking) and Warmińsko-Mazurskie. The least noticeable rise in female candidacy occurred in those regions which had already a relatively high quota (over 30\%) of women on their lists in 2010, that is Pomorskie and Mazowieckie.

This data involves all registered electoral committees and electoral lists put forward by them. This also means that those electoral bodies that had little chance in the competition, as they did not, for instance, put forward electoral lists in all constituencies, were also included in the research. As the study concerning regional assembly elections in 1998-2014 shows (Alberski, Cichosz, 2017), the nationwide parliamentary parties are most likely to win mandates. It is therefore valid to narrow down the analysis to focus on 
such parties and the effects of their personnel policies, including those regional political entities which achieved the election threshold.

Table 2

Women's positions on the lists of electoral committees participating in the division of mandates by region

\begin{tabular}{|l|c|c|c|c|c|r||}
\hline \multirow{3}{*}{ Region } & \multicolumn{7}{|c|}{ Number of women } \\
\cline { 2 - 7 } & \multicolumn{2}{|c|}{ I position } & \multicolumn{2}{c||}{ II-V positions } & \multicolumn{2}{c||}{ other positions } \\
\cline { 2 - 7 } & $\mathbf{2 0 1 0}$ & $\mathbf{2 0 1 4}$ & $\mathbf{2 0 1 0}$ & $\mathbf{2 0 1 4}$ & $\mathbf{2 0 1 0}$ & $\mathbf{2 0 1 4}$ \\
\hline Wielkopolskie & 1 & 7 & 24 & 44 & 56 & 120 \\
\hline Kujawsko-Pomorskie & 4 & 7 & 33 & 36 & 30 & 79 \\
\hline Małopolskie & 5 & 5 & 30 & 30 & 47 & 93 \\
\hline Dolnośląskie & 5 & 5 & 31 & 44 & 43 & 101 \\
\hline Lubelskie & 3 & 4 & 24 & 33 & 40 & 57 \\
\hline Lubuskie & 3 & 2 & 15 & 39 & 44 & 90 \\
\hline Lódzkie & 4 & 3 & 34 & 33 & 45 & 77 \\
\hline Mazowieckie & 9 & 8 & 42 & 49 & 73 & 117 \\
\hline Opolskie & 4 & 3 & 25 & 32 & 38 & 88 \\
\hline Podlaskie & 1 & 2 & 15 & 20 & 28 & 73 \\
\hline Pomorskie & 1 & 1 & 22 & 27 & 46 & 82 \\
\hline Śląskie & 4 & 5 & 36 & 62 & 67 & 121 \\
\hline Podkarpackie & 3 & 5 & 16 & 23 & 35 & 84 \\
\hline Świętokrzyskie & 1 & 2 & 21 & 14 & 69 & 91 \\
\hline Warmińsko-Mazurskie & 4 & 4 & 19 & 39 & 29 & 70 \\
\hline Zachodniopomorskie & 2 & 6 & 24 & 42 & 35 & 82 \\
\hline Poland & 54 & 69 & 411 & 567 & 725 & 1,425 \\
\hline \hline
\end{tabular}

Source: Own work based on National Electoral Commission data.

The data included in Table 2 indicates that women are definitely under-represented in the head positions of electoral lists, that is, those places that offer the biggest chance of winning a mandate. In 2014, women were positioned in the first places in 69 cases, that is $18.5 \%$ of lists included in this part of the analysis. It should be added, however, that this number constitutes a rise in comparison to 2010, when analogically 54 candidates were positioned first, constituting $14.14 \%$ of electoral lists of political entities participating in the division of mandates. When reviewing regional differences in this respect, one might notice the case of Pomorskie, where only one out of 20 electoral lists was headed by a female candidate. This is a repetition of the situation in 2010; it should be stressed, however, that this was the same person, a female candidate from SLD. Women were awarded first places on the lists more often in 2014 than in 2010, especially in Kujawsko-Pomorskie (3 female candidates more, that is, a rise from $16.7 \%$ to $29.2 \%$ ), Zachodniopomorskie (4 female candidates more, a rise from $10 \%$ to $23.3 \%$ ) and Wielkopolskie (6 female candidates more, a rise from $4 \%$ to $23.3 \%$ ). Yet, it should be remembered that in the two latter regions, in 2014 a larger number of electoral committees was taken into account.

As has been mentioned, electoral competition in regional assembly elections is dominated by the largest nationwide political parties, and out of all regional elections it most resembles those to the national parliament. This similarity has been observed since 1989, and even though the structure and description of the regional political markets is shifting, 
this trend seems to be relatively stable. Therefore, it is worthwhile examining how the largest national political parties implement the quota system in regional assembly elections.

Table 3

The position of women on electoral lists of the main political parties

\begin{tabular}{|c|c|c|c|c|c|c|c|c|c|c|}
\hline \multirow{3}{*}{$\begin{array}{c}\text { Political } \\
\text { party }\end{array}$} & \multicolumn{4}{|c|}{ Number of women (total) } & \multicolumn{6}{|c|}{ Number of women on electoral list } \\
\hline & \multicolumn{2}{|c|}{2010} & \multicolumn{2}{|c|}{2014} & \multicolumn{2}{|c|}{ I position } & \multicolumn{2}{|c|}{ II-V positions } & \multicolumn{2}{|c|}{ other positions } \\
\hline & number & $\%$ & number & $\%$ & 2010 & 2014 & 2010 & 2014 & 2010 & 2014 \\
\hline PO RP & 291 & 26.17 & 486 & 43.94 & 16 & 25 & 108 & 130 & 167 & 331 \\
\hline PiS & 268 & 24.43 & 470 & 42.38 & 10 & 12 & 83 & 101 & 175 & 357 \\
\hline PSL & 258 & 23.20 & 470 & 42.77 & 14 & 10 & 93 & 132 & 151 & 328 \\
\hline SLD & 333 & 32.21 & 486 & 44.30 & 14 & 18 & 114 & 149 & 205 & 319 \\
\hline
\end{tabular}

Source: Own work based on National Electoral Commission data.

On the basis of the data presented in Table 3, one may conclude that the electoral lists of committees which did not participate in mandate division are more open to female candidates than the lists of four largest political parties. Among the latter, only the SLD-LR lists in 2014 came close to the national average in terms of the percentage of women on electoral lists. Nevertheless, it must be noted that the participation of women among party candidates significantly rose (by 10-20\%) in 2014 in comparison to 2010 .

The largest number of leading positions on electoral lists ( 25 of them, which is $29.41 \%$ of all first places) was given to female candidates by PO, which is 9 more than in 2010. Secondly, SLD was represented by 18 women (21.17\%) placed first on the lists. When it comes to PiS, in comparison to 2010 the number of female candidates placed first on the lists rose by only 2 (in 2010: 10 female candidates, in 2014: 12 female candidates $-14.11 \%$ ). PSL represents a special case, as in contrast to 2010 this party reduced the number of first places allocated to female candidates in 2014 (10 places, 11.76\%).

In the next section of the electoral list indicated above (places from 2 to 5), the number of female candidates increased, although a difference between the percentage of places allocated to women on electoral lists and the percentage of women in this section is still noticeable. In this case, PO was represented by women in $38.24 \%$ of places (130 places), while PiS in $29.70 \%$ of places (101 places), PSL - 38.82\% (132 places), and SLD $-43.82 \%$ (149 places). Yet, women were over-represented in section III of electoral lists, that is, from positions 6 to the ends of the lists. In the lists of PO they constituted $48 \%$ of all candidates, in PiS - 52.19\%, PSL - 48.66\%, and SLD-LR - 47.32\%.

Yet, when contrasting this data with that of 2010, one should note a change in the personnel strategy of political parties. Although this does not concern the percentage of leading positions allocated to female candidates, which in 2010 was on average $15.51 \%$ for those four parties ${ }^{3}$ (in 2014 it was $18.08 \%$ ), there are shifts in proportions between the percentage of female representation in places 2-5 and later positions. In 2010, in the section of positions from 2 to 5 , the percentage of female candidates was on average $28.59 \%,{ }^{4}$ and in

${ }^{3}$ The data for particular parties is as follows: PO $-18.39 \%$, PiS $-11.49 \%$, PSL $-16.09 \%$, SLD $-16.09 \%$.

${ }^{4}$ The data for particular parties is as follows: PO $-31.03 \%$, PiS $-23.85 \%$; PSL $-26.72 \%$, SLD $-32.76 \%$. 
the section of positions from 6 to the end of the list, it was 26.9\%. ${ }^{5}$ In 2014, these average percentages were, respectively, $37.64 \%$ (section II) and $49.04 \%$ (section III). This means that the quota system was implemented in the construction of electoral lists in regional assembly elections by searching for female candidates, only to allocate them those positions on the lists which offered little chance of winning a mandate.

\section{Female candidates' electoral results}

The number of female candidates who won mandates as councilors in regional assemblies was similar in both elections, as in this group there were only two women more in 2014 than in 2010. A similar situation is also visible in the percentage of women participating in councils, that being $21.8 \%$ in 2010 and $23.1 \%$ in 2014 . This obviously constitutes less than the $35 \%$ required by law, and significantly less than the number of female candidates put forward on the electoral lists. The difference between the percentage of women on the electoral lists and in councils increased significantly, which results from the larger percentage of women on electoral lists in 2014 (by 14.75\%) with little simultaneous increase in their electoral effectiveness, that being at 1.3\% (see Table 4).

Table 4

Candidates elected to regional assemblies in 2010-2014, divided into men and women

\begin{tabular}{|c|c|c|c|c|c|c|c|}
\hline \multirow{3}{*}{ Region } & \multicolumn{4}{|c|}{ Number } & \multirow{2}{*}{\multicolumn{3}{|c|}{$\%$ of women }} \\
\hline & \multicolumn{2}{|c|}{ women } & \multicolumn{2}{|c|}{ men } & & & \\
\hline & 2010 & 2014 & 2010 & 2014 & 2010 & 2014 & difference \\
\hline Wielkopolskie & 6 & 10 & 33 & 29 & 15.4 & 25.6 & +10.2 \\
\hline Kujawsko-Pomorskie & 8 & 6 & 25 & 27 & 24.2 & 18.2 & -6.0 \\
\hline Małopolskie & 8 & 8 & 31 & 31 & 20.5 & 20.5 & 0.0 \\
\hline Dolnośląskie & 10 & 8 & 26 & 28 & 27.8 & 22.2 & -5.6 \\
\hline Lubelskie & 6 & 6 & 27 & 27 & 18.2 & 18.2 & 0.0 \\
\hline Lubuskie & 6 & 5 & 24 & 25 & 20.0 & 16.7 & -3.3 \\
\hline Łódzkie & 13 & 11 & 23 & 22 & 36.1 & 33.3 & -2.8 \\
\hline Mazowieckie & 17 & 21 & 34 & 30 & 33.3 & 41.2 & +7.9 \\
\hline Opolskie & 5 & 5 & 25 & 25 & 16.7 & 16.7 & 0.0 \\
\hline Podlaskie & 2 & 5 & 28 & 25 & 6.7 & 16.7 & +10.0 \\
\hline Pomorskie & 9 & 5 & 24 & 28 & 27.3 & 15.2 & -12.1 \\
\hline Śląskie & 13 & 13 & 35 & 32 & 27.1 & 28.9 & +1.8 \\
\hline Podkarpackie & 4 & 7 & 29 & 26 & 12.1 & 21.2 & +9.1 \\
\hline Świętokrzyskie & 3 & 3 & 27 & 27 & 10.0 & 10.0 & 0.0 \\
\hline Warmińsko-Mazurskie & 7 & 8 & 23 & 22 & 23.3 & 26.7 & +3.4 \\
\hline Zachodniopomorskie & 9 & 7 & 21 & 23 & 30.0 & 23.3 & -6.7 \\
\hline Poland & 126 & 128 & 435 & 427 & 21.8 & 23.1 & +1.3 \\
\hline
\end{tabular}

Source: Own work based on National Electoral Commission data.

In 2014, only in Mazowieckie was the number of female councilors larger than 35\%. In 2010 , this was only the case in Łódzkie. Yet, in 2010, women constituted $30 \%$ or more

${ }^{5}$ The data for particular parties is the following: PO $-24.67 \%$, PiS $-26.43 \%$, PSL $-22.30 \%$, SLD $-34.22 \%$. 
of the regional assembly in three regions (Łódzkie, Mazowieckie and Zachodniopomorskie), while in 2014 only in two (Łódzkie and Mazowieckie).

In six regions the presence of women in councils decreased both in number and in percentage terms. These regions include: Dolnośląskie, Kujawsko-Pomorskie, Lubuskie, Łódzkie, Pomorskie and Zachodniopomorskie. In five regions the number of women in councils stayed the same; these were: Lubelskie, Małopolskie, Opolskie, Śląskie and Świętokrzyskie. In Śląskie, the percentage of women in regional representation rose, which, nevertheless, resulted from the general decrease in the number of councilors. The number of women in regional assemblies increased in five regions: Mazowieckie, Podkarpackie, Podlaskie, Warmińsko-Mazurskie and Wielkopolskie.

In three regions - Wielkopolskie, Podlaskie and Podkarpackie - the increase in the number of women elected to regional assemblies in 2014 was the largest, yet that number was the smallest there in 2010. In the 2010 elections, in 16 regions, the number of women participating in these elections was above average in half of them, and below in the other half. Yet, in 2014, in six regions the percentage of female participation was higher than the average. The rise in the number of female candidates on the lists did not directly translate into an increase in the number and percentage of women in councils.

However, it should be noted that there are constituencies where female candidates were exceptionally effective. For instance, in constituency no. 7 in Mazowieckie, 7 out of 10 mandates were awarded to women.

When it comes to mandates won from particular positions on electoral lists, in the national perspective, the results of the 2010 and 2014 elections are similar. Female candidates who were allocated first five positions on the lists won the largest number of mandates.

Table 5

Positions on electoral lists and mandates won by women, divided into regions

\begin{tabular}{|c|c|c|c|c|c|c|}
\hline \multirow{3}{*}{ Region } & \multicolumn{6}{|c|}{ Number of mandates won by women: } \\
\hline & \multicolumn{2}{|c|}{ I position } & \multicolumn{2}{|c|}{ II-V positions } & \multicolumn{2}{|c|}{ other positions } \\
\hline & 2010 & 2014 & 2010 & 2014 & 2010 & 2014 \\
\hline Wielkopolskie & 1 & 5 & 4 & 4 & 1 & 1 \\
\hline Kujawsko-Pomorskie & 3 & 2 & 5 & 3 & 0 & 1 \\
\hline Małopolskie & 2 & 4 & 5 & 3 & 1 & 1 \\
\hline Dolnośląskie & 3 & 4 & 7 & 4 & 0 & 0 \\
\hline Lubelskie & 2 & 1 & 4 & 5 & 0 & 0 \\
\hline Lubuskie & 2 & 1 & 3 & 3 & 1 & 1 \\
\hline Łódzkie & 4 & 3 & 8 & 6 & 1 & 2 \\
\hline Mazowieckie & 6 & 7 & 8 & 12 & 3 & 2 \\
\hline Opolskie & 3 & 3 & 2 & 2 & 0 & 0 \\
\hline Podlaskie & 1 & 1 & 1 & 3 & 0 & 1 \\
\hline Pomorskie & 1 & 0 & 6 & 4 & 2 & 1 \\
\hline Śląskie & 4 & 4 & 7 & 8 & 2 & 1 \\
\hline Podkarpackie & 3 & 4 & 0 & 3 & 1 & 0 \\
\hline Świętokrzyskie & 0 & 0 & 2 & 2 & 1 & 1 \\
\hline Warmińsko-Mazurskie & 4 & 4 & 2 & 4 & 1 & 0 \\
\hline Zachodniopomorskie & 1 & 3 & 7 & 4 & 1 & 0 \\
\hline Poland & 40 & 46 & 71 & 70 & 15 & 12 \\
\hline
\end{tabular}

Source: Own work based on National Electoral Commission data. 
The number and percentage of mandates awarded to female candidates in first positions on electoral lists in the general number of mandates won by women rose from $31.7 \%$ to $35.9 \%$. When it comes to positions from 2 to 5 , it fell from $56.3 \%$ to $54.7 \%$. The mandates won from positions 1 to 5 constituted $88.1 \%$ of all mandates won by women in 2010 and $90.6 \%$ in 2014. In turn, $11.9 \%$ of mandates won from lower places on electoral lists were gained by female candidates in 2010, and $9.4 \%$ in 2014 . Obviously, the crucial thing is the number of mandates awarded to a particular electoral committee in each constituency. For instance, in the case of winning two mandates, at least one will be won by a candidate from a position lower down than no. 1 .

Only in Świętokrzyskie did none of the female candidates placed first on the list win the mandate, neither in 2010 nor in 2014. However, this region belongs to one of those regions were women were awarded the smallest number of first places on lists in the electoral committees which participated in mandate division. Similarly, the only female candidate positioned first on the electoral list of SLD in Pomorskie in 2014 did not win the mandate. In this case, the party did not achieve the election threshold.

The importance of the leading position on electoral lists is evident when one analyzes the percentage of female candidates placed first on the lists, placed from 2 to 5 , and placed further away from the top, taking into account the committees of political parties with the largest support, and those local committees which participated in the mandate share. Among women in leading places in $2010,74.1 \%$ won mandates, and $66.7 \%$ in 2014. Among women located in places $2-5,17.3 \%$ won mandates in 2010 , and $12.3 \%$ in 2014. Female candidates located further down the list won $2.1 \%$ of mandates in 2010 , and only $0.8 \%$ in 2014 . When divided into regions, all women who were located as the first candidates on the lists in 2010 won mandates in Łódzkie, Podkarpackie, Podlaskie, Pomorskie, Śląskie, Warmińsko-Mazurskie and Wielkopolskie. In 2014, only in Łódzkie, Opolskie and Warmińsko-Mazurskie regions did all female candidates from first places win mandates.

Table 6

Positions on electoral lists and mandates won by female candidates, divided by electoral committees

\begin{tabular}{|l|c|c|c|c|c|c||}
\hline \multirow{2}{*}{$\begin{array}{c}\text { Electoral } \\
\text { committee }\end{array}$} & \multicolumn{6}{|c|}{ Number of mandates won by women: } \\
\cline { 2 - 7 } & \multicolumn{2}{|c|}{ I position } & \multicolumn{2}{c||}{ II-V positions } & \multicolumn{2}{c||}{ other positions } \\
\cline { 2 - 7 } & $\mathbf{2 0 1 0}$ & $\mathbf{2 0 1 4}$ & $\mathbf{2 0 1 0}$ & $\mathbf{2 0 1 4}$ & $\mathbf{2 0 1 0}$ & $\mathbf{2 0 1 4}$ \\
\hline PO RP & 15 & 23 & 42 & 34 & 10 & 5 \\
\hline PiS & 10 & 11 & 15 & 19 & 3 & 2 \\
\hline PSL & 5 & 9 & 6 & 16 & 2 & 5 \\
\hline SLD & 10 & 1 & 7 & - & - & - \\
\hline Others & - & 2 & 1 & 1 & - & - \\
\hline Total & 40 & 46 & 71 & 70 & 15 & 12 \\
\hline
\end{tabular}

Source: Own work based on National Electoral Commission data.

Regarding the electoral committees of the main political parties, the largest number of women were elected from the list of PO -67 and 62 respectively in each election. This constituted about a half of all mandates won by female candidates, although the number of women representing PO in regional assemblies decreased. In terms of the 
number of mandates won by women, PiS comes second, as the number of its female representatives in regional assemblies rose from 28 to 32 . The most significant increase is observed in PSL. In 2010, 13 women represented this party in regional assemblies, while in 2014 there were 30 women from PSL. In the case of the three political parties with the largest support, the number of women elected from the first positions on electoral lists increased; in terms of numbers, the most significant increase occurred in PO, in terms of percentage - in PSL. Female candidates from places further down the list won mandates only in the committees with the largest support. It should also be noted that the number of female representatives of political parties in regional assemblies stayed the same and amounted to 125 councilors. Regarding the two parties with the largest support (PO and PiS), rarely did a female candidate from the first place fail to gain a mandate. In the 2010 elections, PO had only one such case among 16 female candidates, while in 2014 - two such cases among 25 female candidates. All female candidates positioned as the first on PiS's electoral lists in 2010 won mandates, while in 2014 among the twelve female candidates from the first place on PiS's list, only one failed to win the mandate.

\section{Conclusions}

In the regional assembly elections in 2014, the number of women represented on the lists of electoral committees significantly increased in comparison to the 2010 elections, rising by $49.47 \%$. The legally introduced quota was exceeded, as women constituted about $45 \%$ of all candidates. A larger than average number of female candidates who won mandates may be found in two regions: Łódzkie and Mazowieckie. In both elections, women constituted over one-third of elected councilors. Only in Mazowieckie was the percentage of female candidates higher than legally required quota in the 2014 elections. The region which was the least "female candidate-friendly" was Świętokrzyskie, in which both before and after the introduction of the quotas, only one in ten mandates was awarded to a woman.

Although electoral committees did implement the quota law, they did not introduce it in terms of the place allocation on electoral lists, particularly when it comes to first positions. Still over $80 \%$ of leading places on electoral lists were reserved for male candidates. It may be deduced that since 2010 the strategy of the largest political parties in terms of constructing their electoral lists has changed. This does not concern women in the leading places on lists, which increased, albeit insignificantly, but the proportion of female candidates in places from 2 to 5, or 6 and lower. While in 2010 the percentage of women in places 2-5 and from 6 to the end was larger, in 2014 these proportions were reversed. Such a situation may be explained by the smaller political clout of women in comparison to men (Cwalina, Falkowski, 2005, p. 219), but also by the smaller overall number of women engaged in party politics. In order to fulfil the quota requirement, political parties were forced to look for female candidates, thus reaching deep into their support (e.g. family members, friends, etc.) to find persons previously unengaged with politics and without electoral potential. A similar mechanism has been observed regarding parliamentary elections (Flis, 2012, p. 94). In this way, the percentage of women on 
electoral lists increased, but the situation did not offer a fair chance to female candidates to win mandates.

The number of female representatives of the largest parties in regional assemblies did not change. Among women elected to regional assemblies, about one-third were candidates located on first positions on electoral lists. It was much easier to gain mandates from leading places than from further down the electoral lists. In 2014 elections, among all female candidates positioned first on the lists of electoral committees which participated in mandate division, two-thirds won mandates, while in the same elections, among female candidates positioned below place 5 , only one candidate in a hundred was awarded a mandate.

\section{Bibliography}

Alberski R., Cichosz M. (eds.) (2017), Gra o regiony 2014. Wybory do sejmików województw, Instytut Politologii Uniwersytetu Wrocławskiego, Wrocław.

Caul M. (1999), Women's representation in parliament. The Role of Political Parties, "Party Politics", vol. 5 , no. 1.

Cichosz M., Starzyk A. (2017), Przyszli władcy regionów. Rzecz o kandydatach w wyborach do sejmików województw w 2014 r., in: Gra o regiony 2014. Wybory do sejmików województw, eds. R. Alberski, M. Cichosz, Instytut Politologii Uniwersytetu Wrocławskiego, Wrocław.

Cwalina W., Falkowski A. (2005), Marketing polityczny. Perspektywa psychologiczna, Gdańskie Wydawnictwo Psychologiczne, Gdańsk.

Flis J. (2012), Skuteczność parytetu, in: Wybory parlamentarne 2011, eds. A. Turska-Kawa, W. Wojtasik, Remar, Katowice.

Flis J., Gendźwiłł A. (2017), Przedstawiciele i rywale - samorzadowe reguly wyboru, Fundacja im S. Batorego, Warszawa.

Fuszara M. (2007), Polityka jako obszar nierówności kobiet i mężczyzn, in: Czarna księga kobiet, ed. C. Ockrent, Wydawnictwo W.A.B., Warszawa.

Fuszara M. (2011), Kobiety w polityce, in: Gender w spoleczeństwie polskim, eds. K. Slany, J. Struzik, K. Wojnicka, Wydawnictwo Nomos, Kraków.

Gendżwiłł A., Raciborski J. (2014), Jak głosuja wyborcy w warunkach preferencyjnych list wyborczych: przypadek Polski, "Decyzje" nr 22.

Matland R. E. (2003), Zwiększenie uczestnictwa politycznego kobiet: nominacja do ciat ustawodawczych a systemy wyborcze, in: Aktorzy życia publicznego. Płeć jako czynnik różnicujacy, ed. R. Siemieńska, Wydawnictwo Naukowe „Scholar”, Warszawa.

Musiał-Karg M. (2014), Polacy o aktywności kobiet w polityce. Czy należy wprowadzać dodatkowe mechanizmy zwiększające udziat Polek w życiu politycznym?, "Political Preferences", no. 8.

Niżyńska A. (2011), Kandydatki w wyborach samorządowych w 2010, Instytut Spraw Publicznych, Warszawa.

Norris P. (2004), Electoral Engineering, Cambridge University Press, Cambridge.

Siemieńska R. (2005), Mechanizmy zwiększania reprezentacji kobiet w parlamencie - z perspektywy doświadczeń polskich wyborów 2001 roku, in: Płeć, wybory, władza, ed. R. Siemieńska, Wydawnictwo Naukowe Scholar, Warszawa.

Sznajder A. (2009), Kobiety i władza - analiza czynników sprzyjajacych większej aktywności politycznej kobiet, in: Kobiety we wspótczesnej Europie, ed. M. Musiał-Karg, Wydawnictwo Adam Marszałek, Toruń. 
Urbaniak K. (2011), Parytety i kwoty wyborcze a Konstytucja RP, "Przegląd Politologiczny” no. 2.

Wawrowski Ł. (2007), Polityka równych szans. Instytucjonalne mechanizmy zwiększania partycypacji kobiet w strukturach politycznych na przykładzie państw Unii Europejskiej, Wydawnictwo Adam Marszałek, Toruń.

\section{Wdrażanie systemu kwot w wyborach do Zgromadzenia Regionalnego: analiza wyników wyborów w kontekście reprezentacji kobiet na listach wyborczych}

\section{Streszczenie}

Artykuł dotyczy wybranych aspektów realizacji systemu kwotowego w wyborach do sejmików województw w Polsce. Analizą porównawczą objęte zostały dwie elekcje w 2010 (przed wprowadzeniem systemu kwotowego) i 2014 r. (po wprowadzeniu). Zasadnicze pytania, na które autorzy poszukują odpowiedzi dotyczą liczby kobiet reprezentowanych na listach wyborczych komitetów wyborczych w 2010 r. i 2014 r. oraz liczby mandatów w sejmikach województw zdobytych przez kobiety przed i po wprowadzeniu systemu kwotowego, a także zależności między miejscem na liście a uzyskaniem mandatu przez kobiety. Zwrócono uwagę na strategie kadrowe partii politycznych. Wybory do sejmików województw charakteryzowały się największym stopniem upartyjnienia wśród wszystkich rodzajów wyborów samorządowych.

Wprowadzenie systemu kwotowego spowodowało wzrost liczby kobiet na listach wyborczych, ale nie wpłynęło na wzrost liczby mandatów uzyskiwanych przez kobiety. Jedną z przyczyn takiej sytuacji mogły być strategie obsadzania miejsc na listach wyborczych przez największe pod względem uzyskanego poparcia partie polityczne. Mniejsza, od przyjętej w prawie wyborczym kwoty, reprezentacja kobiet na pierwszych miejscach list wyborczych i nadreprezentacja kobiet na miejscach dalszych, dających mniejsze szanse na zdobycie mandatu. Bazę źródłową wykorzystaną w trakcie badań stanowiły dane udostępniane przez Państwową Komisję Wyborczą.

Słowa kluczowe: kobiety, system kwotowy, wybory, sejmiki województw, partie polityczne 
